\title{
The Certificate of Building Use of Rights (Shgb) that has been out Duration of Ownership, with Execution of Sita Object Guarantee to Land
}

\author{
Heru Soetanto Putra*, Abdul Gani Abdullah, Gunawan Djajaputra \\ Tarumanagara University, Indonesia
}

Received: 16/06/2020

Accepted: 16/07/2020

Published: 20/07/2020

\begin{abstract}
The length of the civil litigation process regarding land from the District Court, the High Court to the final level and legal protection of the assets seized as well as proof of ownership of land or building rights are certificates. Based on these problems, it can be analyzed the validity of the execution of the object of confiscation of land against the Land Use Certificate (SHGB) that has expired and can be analyzed what steps must be taken in protecting the assets confiscated in a civil case through the Civil Procedure Code, the Agrarian Regulation Indonesia, Indonesian Auction Regulations. Based on this analysis, the Confiscation, Execution and Building Rights Auction activities that have expired are the conclusions of this study.
\end{abstract}

Keywords: Confiscated object, Certificate of building, Confiscation, Civil Engineering, Auction

\section{Introduction}

One of the most important factors that are clearly considered and regulated is land management. Because the amount is limited and the need for land continues to increase, making land has a high value seen from any perspective, including the perspective of sociology, anthropology, psychology, politics, military and economics. So high land values because humans as social beings will defend their land in any way. Various human interests that conflict with each other relating to the control and ownership of land rights cause many cases of land. Problems that occur in the community relating to the control and ownership of land rights that require the government to make legal rules in the field of land (1). Written land law is realized by the existence of Law Number 5 of 1960 concerning Basic Regulations on Agrarian Principles (hereinafter referred to as UUPA). Since the promulgation of the UUPA, the National Agrarian Law has revoked regulations and decisions made during the Dutch East Indies Government, including Agrarishe Wet Stb. 1870 No. 55 and Agrarische Besluit Stb. 1870 No.118 (1), (2). In the UUPA, the objectives of the enactment of the UU are: (1) Laying the foundations for the drafting of the National Agrarian Law, which will be a tool to bring prosperity, happiness and justice to the State and the people, especially the peasants, in the context of society just and prosperous; (2) Laying the groundwork for establishing the unity and simplicity of land law; (3) Laying the groundwork to provide legal certainty regarding land rights for the whole people. The absence of strict and comprehensive regulations that guarantee and provide legal certainty over the execution of a confiscated object in the form of land when the validity period expires. So in this paper the author wants to discuss in more detail about the transfer of land rights as objects of confiscation due to a court decision and legal certainty over its

*Corresponding author: Heru Soetanto Putra, Tarumanagara University, Indonesia. E-mail: herusoetantoputra@gmail.com execution. Based on the above, the authors are interested in conducting research on how the legal certainty of the execution of the object seized collateral for land that has expired.

1 Execution of confiscated objects against land with a certificate of right to use for a building that has exhausted

1) Confiscation Guarantee: Sita (Beslag) is a legal action of a court for a Defendant's movable and immovable property at the request of the Plaintiff to be monitored or taken to ensure that the Plaintiff's claim / authority of the Plaintiff does not become void. (1), (2), (3). Understanding foreclosure or conservatoir beslag stipulated in Article 227 paragraph 1 HIR, Article 261 paragraph $1 \mathrm{RBg}$ (2), (3): (a) Confiscate debtor's goods as long as a decision has not been handed down in the case; (b) the goal is that the goods are not embezzled or sequestered by the Defendant during the trial process, so that when the verdict is implemented, the repayment of the debt demanded by the plaintiff can be fulfilled by selling the confiscated goods.

2) Collateral Confiscation Process: Confiscation of the property of the defendant can be carried out if there is a concern that the defendant will divert his goods. Usually it relates to lawsuits over payment of money or delivery of goods. With the confiscated goods, the goods (after the decision has legal status remains excecutorial beslag will be auctioned if the Defendant does not implement the decision and the auction will be used to pay the plaintiff.

Guarantee seizure is confiscation that is used as a preparation for a decision to be carried out if it has permanent legal force (1), (2), (3), (4), (5). This is done so that later judicial proceedings and court decisions are not in vain. The confiscation of preparations aims to protect the disputed property (the treasured assets) from being sold or transferring their rights to someone else. This seizure also aims to ensure that the lawsuit is not empty (illusory), and maintain the 
certainty of the object of execution. In the case between the Tangerang Dharmaputra Foundation and Tjoa Sin Goan discussed earlier, the parties in this case the Tangerang Dharmaputra Foundation as a Legal Entity established based on existing legal provisions in Indonesia and Tjoa Sin Goan as Indonesian citizens have chosen to settle disputes in the legal field. Civil litigation with civil litigation. Civil Law is a regulation that regulates rights and obligations between individuals in social life. In the civil court itself, the settlement of the case is made in the form of a decision, the decision can be distinguished between the decision and the decision. The verdict is used as a term in a lawsuit case, in a lawsuit the case ends with a decision (contentious). Whereas the determination is used in a civil case (voluntary) (6). Settlement of cases by the parties through a civil court is in accordance with Article 1 paragraph (3) of the 1945 Constitution of the Republic of Indonesia which states that the Republic of Indonesia is the State of Law. Therefore, any problems that occur must be resolved by the provisions of applicable law. That the Dharmaputra Foundation has filed a civil suit against the law against Tjoa Sin Goan in the Tangerang District Court with a register number dated August 26, 2010. That the Dharmaputra Foundation in addition to filing a collateral confiscation in a civil suit also filed a separate seizure guarantee. Submitting a request for confiscation to guarantee the payment of compensation for damages caused by the defendant, if the verdict of the panel of judges accepts the suit and punishes the Defendant to make the payment. This is in accordance with the provisions of Article 226 and Article 227 HIR or Article 720 Rv or based on SEMA No. 5 of 1975 , confiscation and order of confiscation, starting from the request or request of the plaintiff. In confiscating collateral, the legal basis for confiscation of property belonging to the defendant is Article 227 paragraph (1) HIR / Article 261 paragraph (1) R.bg. This confiscation was carried out for both the movable and immovable property of the defendant. These items are either in the hands of the defendant or are being controlled by another party. In terms of the case between the Foundation Dharmaputra Tangerang as plaintiff against Tjoa Sin Goan as Defendant objects belonging to the defendant presented for sequestration is the form of the object is not moving, that's a plot of land and house located at Princess Island VII Block VII 01 No. 42 Modernland, City Tangerang belongs to Defendant SHGB No. 651 / Cikokol . In the confiscation of confiscated beslag, it must be the property of the defendant, not belonging to a third party, because what can be used as collateral in a case is only the property of the defendant as a litigant. The main reasons for the seizure request according to Article $227 \mathrm{HIR}$ and Article $720 \mathrm{Rv}$, namely:

(a) There is a concern or suspicion that the defendant:

1) Looking for ways to embezzle or alienate their assets;

2) This was done during the case inspection process.

(b) The concern or suspicion must be objective and objectively reasonable:

1) The plaintiff must be able to show facts about the defendant's steps to embezzle or alienate his property during the inspection process;

2) At least the plaintiff can show an objective indication of the existence of the defendant's efforts to eliminate or alienate the goods in order to avoid a lawsuit.

(c) There is a close relationship between the contents of the lawsuit and the confiscation, which if the confiscation is not carried out and the defendant misappropriates the assets, resulting in losses to the Plaintiff.

The assessment of the reasons for the confiscation petition is the authority of the judge examining the case. Judges are free to judge whether the reasons have objective or subjective qualities. In addition, the plaintiff is obliged to mention the identity of the goods submitted in the confiscation guarantee. Request for confiscation can be submitted simultaneously with the lawsuit, or separately in a separate letter. In this case, the Plaintiff filed a request for confiscation of collateral incorporated in a lawsuit dated August 26, 2010 and was registered Number: 475 / PDT.G / 2010 / PN.TNG and also filed a separate application in the seizure request letter dated March 9, 2010. Reason the plaintiff in the confiscation request:

(a) That the Petitioner is the Plaintiff who has filed a lawsuit against the law in the Tangerang District Court with Case Number 475 / PDT.G / 2010 / PN.TNG against Tjoa Sin Goan as the Defendant;

(b) That the Defendant could not account for student savings ranging from kindergarten to high school level at the Dharmaputra Educational Foundation in Tangerang amounting to Rp. 153,864,200 (one hundred fifty three million eight hundred sixty four thousand two hundred rupiahs) held in the account of Bank Ekonomi Account Number 2692970878 in the name of the Defendant;

(c) That the Defendant could not be held responsible for the remaining / difference in student activities ranging from Kindergarten to High School Level at the Dharmaputra Educational Foundation in Tangerang in the amount of Rp.1,144,519,645 (one billion one hundred forty four million five hundred and nineteen six hundred forty five rupiah) which deposited in the Bank Ekonomi account Account Number 2602070061 in the name of the Defendant.

(d) That to ensure that the Plaintiff's claim does not become useless, confiscation of the following objects should be placed:

Land and buildings situated at Princess Island Block VII

VII 01 No. 42 Modernland, Tangerang City on behalf of the Defendant , along with everything that is now / or later established on that land which due to its nature and designation or according to custom / legal regulations (Law) is considered as a fixed object (immovable). In submitting an application for confiscation, the Dharmaputra Foundation as the Petitioner also submitted evidence of documents supporting the arguments of the petition:

a. Photocopy of Deed of Establishment of the Dharmaputra Tangerang Education Foundation in 1980 based on deed number 05 of 1980 made before the Notary Mrs. Nuryani Dwi, SH dated 7 February 1980, marked P-1A;

b. Photocopy of Deed of Amendment to the Articles of Association of the Dharmaputra Education Number 114 dated October 7, 1994, marked P-1B;

c. Photocopy of Deed of Adjustment to the amendment to the Articles of Association with Notary Deed Agus Santoso Suryadi, SH, MH, M.Sc., M.Kn.Number 02 dated May 2, 2007, marked P-2;

d. Photocopy of student savings account account deposited in the account of Bank Ekonomi Account Number 2602070878 in the name of the Defendant, marked P-3;

e. Photocopy of proof of returning student savings totaling Rp. 392,348,200 (three hundred million ninety two million three hundred and forty eight thousand two hundred rupiah) in the form of a list of names of students returning their savings with the date and amount of the refund, marked (P-4); Which proves the return of student savings.

f. Photocopy of proof of return of student savings by Defendant Stage I amounting to Rp. 50,000,000 (fifty million rupiahs) marked with $\mathrm{P}-5 \mathrm{~A}$; 
g. Photocopy of proof of returning student savings by Defendant Phase II amounting to Rp. 188,484,000 (one hundred eighty eight million four hundred eighty four thousand rupiah), marked P-5B;

h. Photocopy of receipt of loan money from the coach to be used to return the shortage of student savings to students and / or parents of students: 1) Rp. 153,864,200 (one hundred fifty three million eight hundred sixty four thousand two hundred rupiah) with details of $\mathrm{Rp}$. $150,000,000$ (one hundred and fifty million rupiah) on April 16, 2009, marked as P-6A; 2) In the amount of Rp. 3,130,100 (three million one hundred thirty thousand one hundred rupiah) on August 3, 2009, marked P-6B; and 3) Rp. 734,100 (seven hundred thirty four thousand one hundred rupiah) on August 29, 2009, marked P-6C.

i. Photocopy of Defendant's statement letter will be responsible for the shortage of student savings which cannot be returned to students who according to the Defendant is only Rp 140,000,000 (one hundred and forty million rupiah), marked with P-7;

j. Photocopy of student savings accounts starting from kindergarten, elementary, junior high, and high school level which are stored in Bank Ekonomi Account Number 2602070061 in the name of Defendant, marked P-8;

k. Photocopy of detailed evidence of income and expenditure of activities from kindergarten, elementary, junior high, and high school levels as follows: 1) Photocopy of report on the receipt of money for the activities of the head of the education and teaching section of the 2005/2006 school year with the difference between the income minus the expenditure of Rp. 559,365,000 Rp. 196,088,630 = Rp. 363,276,370 (three hundred sixty three million two hundred seventy six thousand three hundred seventy rupiahs), marked with P-9A, P-9A1 and $\mathrm{P}-9 \mathrm{~A} 2$; 2) Photocopy of the report on the receipt of money for the activities of the head of the education and teaching section for the 2006/2007 school year, with the difference in revenue and deducted by expenditure of $\mathrm{Rp}$. 555,120,000 - Rp. 270,011,590 = Rp. 285,108,410, - (two hundred eighty-five million one hundred eight thousand four hundred and ten rupiah), marked with P-9B;3) Photocopy of report on receipt of money for the activities of the head of the education and teaching division for the $2007 / 2008$ academic year, with the difference in revenue and deducted by expenditure of Rp. 563,350,000 - Rp. $363,073,585=$ Rp. 200,276,415 (two hundred million two hundred seventy-six thousand four hundred and fifteen rupiah), marked P-9C; and 4) Photocopy of the report on the receipt of money for the activities of the head of the education and teaching division for the 2008/2009 academic year, with the difference in revenue and deducted by expenditure of Rp. 522,50,000 - Rp. $266,646,550=$ Rp. $295,858,450$ (two hundred ninety five million eight hundred fifty eight thousand four hundred fifty rupiah), marked P-9D;

1. Photocopy of evidence of the letter of deactivation of the Defendant as the Trustees of the Tangerang Dharmaputra Education Foundation, marked P-10A;

$\mathrm{m}$. Photocopy of evidence of the dismissal of the Defendant's letter as the Trustee of the Dharmaputra Education Foundation in Tangerang, marked P-10B;

n. Photocopy of receipt of the Tangerang Metro District Police Assistant Investigator, marked with P-10C;

o. Photocopy of proof of subpoena I by the Plaintiff's attorney so that the Defendant is immediately responsible for student savings and activities of the student, marked P$11 \mathrm{~A}$; p. Photocopy of proof of subpoena II by the Plaintiff's attorney so that the Defendant is immediately responsible for the student savings and the activities of the student, marked P-11B;

q. Photocopy of summons evidence III by the Plaintiff's attorney so that the Defendant is immediately responsible for the student savings and the activities of the student, marked P-11C;

After the panel of judges examining the case considering the arguments and evidence as the basis for the petition, on March 17, 2011 issued Determination Number: 475 / PDT.G / 2010 / PN.TNG, which decided as follows: (a) to grant the claim of confiscation of the Plaintiff as mentioned above and (b) ordered the Registrar / Bailiff of the Tangerang District Court or if unable to be replaced by his authorized representative accompanied by 2 (two) witnesses who fulfilled the requirements as specified in Article $197 \mathrm{HIR}$ to confiscate (Conservatoir Beslag) the Defendant's assets in the form of Land and Building located on Jalan Pulau Putri VII block VII 01 No. 42 Modernland, Kota Tangerang-Banten on behalf of the Defendant.

Determination of the judge who states that the petition for confiscation is one of the forms of a judge in the form of an interlocutory $\mathrm{p}$ judge containing orders that must be carried out by the parties to the litigation to facilitate the judge completing the examination of the case, before he decides the final decision. The interim messenger does not stand alone, but is a unity with the final decision on the subject matter. That the judge on a request to make injunction before dropping the final decision with regard to the subject matter.

3) Execution of Confiscated Collateral: according to Prof. R. Subekti is the implementation of a decision that can no longer be changed, voluntarily obeyed by the disputing party. So in the meaning of words, the execution already implies that the losing party inevitably must obey the decision voluntarily, so the decision must be forced upon him with the help of the general power. What is meant by public power is the police even if necessary by the military (armed forces) (4). Whereas in the case between the Tangerang Dharmaputra Foundation as the Plaintiff and Tjoa Sin Goan as the Defendant despite Determination Number 475 / PDT.G / 2010 / PN.TNG dated March 17, 2011 concerning Confiscation of Guarantees. Furthermore, it was strengthened by Decision Number $475 /$ PDT.G / 2010 / PN.TNG dated June 13, 2011 which stated that the Confiscation Guarantee was legal and valuable. The process of execution of objects placed as collateral for the implementation of the fulfillment of the decision is not necessarily able to be carried out. This is because the execution of confiscation of collateral is carried out, if the Defendant does not implement the decision of a judge with permanent legal force. In the case between the Tangerang Dharmaputra Foundation as the Plaintiff and Tjoa Sin Goan as the Defendant, even though the Plaintiff was won in the first instance lawsuit, the Defendant filed an appeal against the decision (7). The Defendant who did not accept the Tangerang District Court Decision No: 475 / Pdt.G / 2010 / PN.TNG was read on May 4, 2011 to take legal action by submitting an appeal. The appeal was stated in the minutes of the appeal appeal statement on the District Court Decision No: $475 /$ Pdt.G / 2010 / PN.TNG on May 9, 2011 at the Banten High Court. Whereas the legal remedies filed by the Defendant formally met the requirements for filing an appeal, so that it was appropriate that the Banten High Court accepted the appeal from the Defendant. Whereas in this case, before the case file was sent to the High Court, the parties had been given the opportunity to examine each case in accordance with the notice dated August 15, 2011 and August 19, 2011. 
However, both the Defendants originally did not submit an Appeal and Comparative Memory from the Plaintiff also does not file an Appeal Memory Counter.

That formally before the appeal is decided by the High Court, the appeal can be revoked by the Applicant. If the case file has not been sent to the Court of Appeals. Revocation submitted to the district court concerned, then by the clerk was made the deed revocation of the appeal request. The new verdicts obtain permanent legal force after the appeal period ends. At the time of the appeal level there was no revocation by the appellant (3). The parties in this case did not file an appeal memory or counter memory appeal. In addition, there was no revocation of the appeal submitted by the appeal applicant. The Panel of Judges examining the case continued the examination of the case. Because there is no appeal or counter memory of the appeal submitted by the parties, the panel examined the appeal based on legal considerations in the decision issued by the Tangerang District Court Judges who examined the case. After the High Court has observed that all of the legal facts and / or evidence have been properly and correctly considered by the First-rate Judges according to the law, therefore the legal considerations of the First-Level Judges were taken over by the High Court and used as their own considerations in deciding this case. . Based on these considerations, the Court of Appeal is of the opinion that the Tangerang District Court's decision dated May 4, 2011 Number: 475 / Pdt.G / 2010 / PN.TNG for which an appeal was appealed may be retained, therefore it must be upheld. Whereas the verdict decided by the Panel of Judges examining the case in Decision Number 74 / Pdt / 2011 / PT.Btn dated October 27, 2011, namely: (a) Receive an appeal from the Defendant originally Defendant; (b) To affirm the Tangerang District Court Decision dated May 4, 2011 Number 475 / Pdt.G / 2010 / PN.TNG for which the appeal was filed; (c) Punishing the Appellant Previously the Defendant to pay the costs of this case in the two court levels, which in the level of appeal was Rp. 150,000 (one hundred fifty thousand rupiah).

Decision Number 74 / Pdt / 2011 / PT.Btn has been notified to the original Appellant Defendant on November 14, 2011, then on November 25, 2011 verbally stated the appeal request, as evidently in the deed of appeal application Number: 475 / Pdt.G / 2010 / PN. TNG and accompanied by Cassation Memory on December 9, 2011. The Respondent of Cassation / Plaintiff / Compared has submitted an answer to the cassation memory dated January 10, 2012. The Supreme Court in checking a case that after looking at the arguments put forward by the parties to convince the judges who hear cases and has done legal considerations. So that on 12 September 2012 makes decision $\mathrm{n}$ indicated in the Decision No. 823 K / PDT / 2012 in the verdict as follows: (a) Refuse an appeal request from the Appellant: Tjoa Sin Goan; and (b) Punish the Cassation Applicant / Plaintiff to pay the court fee in this cassation rate of Rp. 500,000 (five hundred thousand rupiah). The cassation decision on the case was then notified to the Plaintiff / Respondent of Cassation on May 2, 2013 and to the Defendant / Cassation Appellant on 8 May 2013. That as of the issuance and notification of the Supreme Court's Appeals in the case between the Dharmaputra Foundation against Tjoa Sin Goan, then the examination of the case of tort against the law has permanent legal force, so it is obligatory to carry out immediately. Based on the Cassation Decision Number: 823 K / PDT / 2012, the Defendant is obliged to implement the contents of Tangerang District Court's Decision Number 475 / PDT.G / 2010 / PN. TNG Jo. Banten District Court Decision Number: 74 / PDT / 2011 / PT.BTN among them, as follows: a. The Cassation / Appellant / Defendant / Defendant is declared to have committed an unlawful act resulting in a loss to the Respondent / Appellant / Plaintiff's total amount of Rp. 1,298,383,845 (one billion two hundred million ninety eight million three hundred eighty three thousand rupiah eight hundred forty-five rupiah);

b. The Cassation / Appellant / Defendant / Defendant is sentenced to compensate the Complainant / Appellant / Plaintiff for the illegal acts committed with a total amount of Rp. 1,298,383,845 (one billion two hundred million ninety eight million three hundred eighty three thousand rupiah eight hundred forty-five rupiah); at the same time and at the latest 8 (eight) days after the decision in this case has permanent and definite legal force;

c. The Panel of Judges in their decision based on legal considerations stated that a valid and valuable seizure was carried out by a bailiff in the Tangerang District Court over:

d. A plot of land and a house is located on the road: Pulau Putri VII Block VII 01 No. 42 Modernland, Kota Tangerang on behalf of Defendant SHGB No. $651 /$ Cikokol;

e. Punishing the Cassation / Comparator / Defendant Applicant to pay the costs incurred in the case, which until now has been calculated as Rp. 1,177,000 (one million one hundred seventy-seven thousand rupiah), at the First District Court;

f. Sentencing the Kasai / Appellant / Defendant to pay this case fee in the Court of Appeals, which in the appellate rate is Rp.150,000 (one hundred and fifty thousand rupiah)

g. Punishing the Cassation Appellant / Appellant / Defendant to pay the court fee in this Cassation Decision amounting to Rp. 500,000 (five hundred thousand rupiah).

After the cassation decision is notified to the parties to the litigation to be implemented immediately. However, it was not carried out voluntarily by the Defendant / Appellant / Appellant of Cassation for the Decision on Cassation Number: $823 \mathrm{~K} / \mathrm{PDT} / 2012$. Therefore sequestration that has been placed on the object land and buildings in Housing Modernland Jalan Putri Island VII VII 01 Block 42, Village Coconut Beautiful, District of Tangerang, Tangerang City, transformed into Sita execution which means it can be run directly without the need for the establishment of judges back.

\section{Auction of transfer of land rights in auction for the certificate of building use rights that are exhausted}

\subsection{Legitimate transfer of rights}

Auction includes a special agreement, namely a named agreement, has its own name, namely auction. Auction is an activity of selling agreement as it is also regulated in the Civil Code. The elements contained in the sale and purchase are also contained in the auction, namely: 1) the existence of legal subjects, namely sellers and buyers; 2) there is an agreement, namely an agreement between the seller and the buyer regarding the price; and 3 ) the rights and obligations that arise for the parties, namely between the seller and the buyer. The most essential thing in auctions and buying and selling is the delivery of goods which become objects in the sale and purchase or auction and payment of the price of the object. Basically the auction is the sale of goods to the public or in public. Because of that, the auction is often referred to as general sales. The fundamental difference between auctions and buying and selling is found in the implementation process, namely where the buying and selling process is 
carried out between individuals, while the auction is conducted between individuals with the public / public.

Auction as a sale and purchase agreement is a consensual agreement which means that the auction has been born as a legal and binding agreement of the parties, also has legal force at the time of the agreement between the seller and buyer, the main elements of which are auctioned goods and auction prices, which happens when the auctioneer for the seller's sake appoints the highest bidder who reaches the limit price as the auction buyer. This consensual nature is emphasized in article 1458 of the Civil Code which states that buying and selling is considered to have occurred between the two parties when they have reached an agreement on goods and prices, even though the item has not been submitted nor the price has been paid. The auction agreement has not transferred the ownership rights, the new auction has granted the buyer the right to claim the ownership of the goods sold through the auction. The sale of auctions originating from the execution of collateral items, the auction is carried out by order of the law by the competent authority, not from the owner of the goods. In legal actions concerning auction of collateral items: 1) when collateral is handed over to the bank as an agreement of credit of the credit agreement, the act is a civil law authority. 2) When collateral is burdened with mortgage rights and is registered at the land office, the act is the legal authority of the Republic. 3) When the goods are handed over to the PN executing agency with the provisions of civil procedural law, the act is a public law. 4) When auction officials appoint auction buyers, for the seller's sake. Auction officials as public officials, carry out civil legal actions in the power of civil law, because auction officials cannot act using their public power and authority to regulate auction winners, as well as the amount of the bid price that becomes a winner in the auction. The auction winner must be returned to the civil attorney, namely the highest bidder at the price agreed by the auction buyer and seller (represented by the auction official), among the existing bidders.

\subsection{The validity of the transfer of rights auction when the auction object is in the form of a building right certificate that has expired}

Auction is the sale of an object into an amount of money. The elements of buying and selling are contained in the elements in the auction. What distinguishes the auction from buying and selling is the process. Where in a sale auction is carried out in public, preceded by efforts to gather interested people through announcements / publications to the general public, carried out by and or in front of auction officials as intermediaries, prices are formed by means of verbal ups and downs and downs and / or written. the elements contained in the sale and purchase are also contained in the auction, namely the existence of legal subjects, sellers and buyers, the existence of an agreement between the seller and the buyer regarding the price, the rights and obligations arising for the parties sellers and buyers. Thus the auction has the same legal character as buying and selling, with the advantages of selling in the form of announcements or publications to the public and how to bid. In auctions whose rights are transferred to the winner of the auction are the object of the sale and purchase object and / or property rights attached to the item.

Auction as an agreement shows the legal character of buying and selling, namely: (1) There are two parties to the agreement, namely seller and buyer; (2) There is an agreement or agreement between the seller to transfer the ownership rights to the goods to the buyer and the buyer's agreement to surrender the amount of money, because the nature of the sale and purchase is consensual, agreement; (3) There are goods which are the object of buying and selling; (4) There is a certain price agreed in the form of money; (5) It is a consensual agreement giving rise to the rights and obligations of sellers and buyers; (6) The transfer of ownership occurs after the material agreement / submission based on the minutes of auction. In the case of the case between the Dharmaputra Foundation and Tjoa Sin Goan, auction sales originating from the execution of collateral items, the auction is carried out by order from the law by the authorities, not from the owner of the goods. The essence of an auction is the delivery of the object which becomes the object of buying and selling or auction and payment of the price of the object. For the Right to Build Certificate which has expired, the land is legally the state's land, but actually there is a right attached to the legal subject of the former right holder. The title of building rights which have expired, can be renewed as long as they meet the requirements for renewal of the building rights as explained above. However, the rights holders can only renew their rights for the object. So in the case of the case between the Foundation Dharmaputra and Tjoa Sin Goan, the house which lies in the way the Island Princess VII Block 01 No. mor 42 Modernland, Tangerang City, based Certificate Broking No. 651 / Kelapa Indah the rights to the building has ended his rights since the date February 9, 2013, then Tjoa Sin Goan and Lenawati (Tjoa Sin Goan's wife) as the holders of Building Use Rights Number 651 / Kelapa Indah are the only legal subjects who have the right to submit renewal rights to the Building Use Certificate Number 651 / Kelapa indah.

In accordance with the provisions contained in article 25 paragraph (2) PP No. 40 of 1996 which states that after the term of the Right to Building and its extension expires, the former right holder can be given renewal of the Right to Building on the same land. The word after has the meaning that after or after. After the time period has expired, it can be interpreted that after the time period has expired or the time period has expired. The former rights holder means Tjoa Sin Goan and Lenawati (Tjoa Sin Goan's wife) as the former holder of Building Rights Number 651 / Kelapa Indah is the only legal subject that can propose renewal of the right to Building Rights Number 651 / Kelapa Indah. Updates Broking given in the same soil, then the house that are located in the Island Princess VII Block 01 No. 42 Modernland, Tangerang City which bases its rights already expired can petition for new rights on the same plot. Thus there are rights that are still attached to the former rights holders, in this case Tjoa Sin Goan and Lenawati (Tjoa Sin Goan's wife) as former holders of Building Use Rights Number 651 / Kelapa Indah. Where this inherent right is the right to propose renewal of the rights to the plot of land.

\section{Conclusion}

The author will put forward conclusions from the problems discussed earlier. The conclusions obtained by the author are as follows.

\subsection{Foreclosure}

In civil cases we know of an arrangement to confiscate the property of the defendant, both movable and immovable property. The act of confiscation is forcibly placing the defendant's property in force. The object foreclosure is in a state of guard. The forced action against the guard is based on a court order or judge. The confiscation can be carried out on the disputed goods or the defendant's belongings which will be used as a means of payment for debtor's debt repayment or the defendant by selling by auction for the confiscated goods. The safeguarding of confiscated goods takes place during the 
inspection process, until a court decision has permanent legal force, which states whether or not the act of confiscation is legal. In the civil procedural law regulates and allows the confiscation of the assets of the debtor or defendant as regulated in Article 227 jo. Article 197 HIR. Article 720 Rv also regulates confiscation. Provisions that justify the implementation of confiscation can also be found in material Civil Law, as in Article 1131 of the Indonesian Criminal Code, all debtors' assets are borne by the payment of their debts to creditors. Confiscation is an exceptional action. The exceptional nature of the foreclosure implicitly contains substantial human rights violations, even though the law allows it. The nature of the violation is rather difficult to get rid of, because the confiscation is carried out before a court decision with permanent legal force is made. The confiscation process in the civil procedural law based on its implementation can be divided into 2 (two), namely: (1) Confiscation of preparation (initial) and (2) Confiscation of Execution. Preparatory confiscation is used as a preparation so that the decision can be carried out if it has permanent legal force, whereas confiscation of confiscation is confiscation that aims to carry out the auction of the defendant's assets to fulfill the decision, if the decision has permanent legal force. As for confiscation of preparations, among others: (1) Confiscation of collateral ( conservatoir beslag ) is confiscation of the defendant's property, both movable and immovable; (2) Confiscation of revindication ( revindicatoir beslag ) is submitted by the owner of the goods so that the goods can be returned; (3) Marital confiscation ( maritale beslag ) is confiscation of joint property owned by husband and wife. Confiscation will be carried out based on the request of confiscation in accordance with Article 227 HIR. The request can be submitted verbally or in writing. Submission of confiscation in writing is considered the most appropriate because it fulfills better judicial administration in the form of a request letter. The request can be made in 2 (two) ways, namely: (1) the request is submitted in a joint letter of claim; and (2) submitted in a separate letter. The request for confiscation must be accompanied by reasons that will be assessed by the judge examining the case. The procedures for confiscating collateral are as follows: (1) confiscation is carried out based on a court ruling; (2) confiscation is carried out by a clerk or seizure; (3) notify the confiscation of the defendant; (4) confiscation was carried out by the bailiff assisted by two witnesses; (5) confiscation is carried out at the place the goods are located; (6) making confiscation minutes (7) putting confiscated goods in their original places; (8) declares confiscation legal and valuable; Safeguarding immovable property which is confiscated as collateral is given to the confiscated party. Confiscation is a legal action that meets the principles of justice, the principle of expediency, and the principle of legal certainty. This is because by confiscation of confiscation of the petition, the plaintiff gets legal protection. This legal protection so that the plaintiff has a guarantee for the goods placed confiscated collateral can be auctioned to meet compensation payments. If in the verdict the judge accepts the claim of the plaintiff and the defendant is sentenced to make compensation payments, but the property of the defendant is gone and the defendant does not have the ability to fulfill the judge's decision.

In a civil lawsuit against the law filed by the Tangerang Dharmaputra Foundation against Tjoa Sin Goan, the Tangerang Dharmaputra Foundation as the Plaintiff may submit a request for confiscation of Defendant's property in the form of movable and immovable property. The form of confiscation submitted by the Dharmaputra Foundation is confiscation of preparation, namely confiscation of security (conservatoir beslag). Submission confiscation immovable owned by the Defendant to the land and the house is located in the street: Princess Island VII Block 01 No. 42 Modernland, Tangerang City on behalf of the Defendant was stated in the lawsuit registered in the Registrar's Office of the Tangerang District Court on October 20, 2010, and filed separately in the guarantee seizure application dated March 9, 2010. Submission of confiscation by the Tangerang Dharmaputra Foundation is appropriate because the lawsuit filed a tort against the law requesting compensation for payment of money or delivery of goods. Confiscation of the property of the defendant is a form of legal protection for the plaintiff of the goods (after the verdict has become excecutorial beslag ) will be auctioned if the defendant does not carry out the decision voluntarily. The results of the auction will be used to carry out the contents of the decision to pay compensation to the plaintiff. Following up on the application for confiscation of collateral by the Dharmaputra Foundation in Tangerang, the Tangerang District Court made Determination Number: 475 / PDT.G / 2010 / PN / TNG whose poetry was: (1) granting the application for confiscation of collateral; (2) instruct the Registrar / Tangerang District Court bailiff to carry out confiscation of property the defendant in the form of land and building located at Jalan Putri Island 01 No. VII VII blocks 42 Modernland, Tangerang-Banten City on behalf of the Defendant. The determination of the judge was in accordance with Article 227 of the HIR because it was filed by the plaintiff against the defendant's object. Following up on the stipulation, the Tangerang District Court issued a notification letter regarding the implementation of the confiscation that will be carried out by the Tangerang District Court Judge. In the Letter of Notification on the Implementation of Collateral Confiscation Number: W / 29.U4 / 93 / HT.04.05 / III / 2011 dated March 29, 2011 containing information on the time of seizure guarantee Monday, April 4, 2011 at 10.00 based on Stipulation Number: 475 / PDT.G / 2010 / PN.TNG dated March 17, 2011. The notice was notified to the Plaintiff, Defendant and Head of Kelapa Indah Village and the parties were requested to be present during the implementation of the confiscation.

\subsection{Decision Execution}

In the trial stage of a civil case, the final stage of the trial is the hearing of the decision reading by the panel of judges examining the case. Judge's decision is the act of the judge in his position as a ruler or state official and it is not impossible that one of the parties will be harmed by the judge's decision because his decision is incorrect, for example due to the inaccuracy of the judge in examining the case. A decision has binding power and force after the decision has permanent legal force (inkracht). A decision is said to be inkracht, if there is no legal action against (verzet), appeal, and cassation and the time limit is up or has used the remedy. Every court decision that has been inkracht must be implemented and followed by the parties both voluntarily and by coercion. In the event that the decision is not carried out by the losing party voluntarily, the party won by the court may request the determination of the execution of the decision. In the case between the Tangerang Dharmaputra Foundation as the Plaintiff and Tjoa Sin Goan as the Defendant, even though the Plaintiff was won in the first-degree lawsuit the Defendant filed an appeal against the decision. The Defendant who did not accept the Tangerang District Court Decision No: 475 / Pdt.G / 2010 / PN.TNG was read on May 4, 2011 to take legal action by submitting an appeal. The legal remedies filed by the Defendant formally met the requirements for filing an 
appeal, so that it was appropriate that the Banten High Court accepted the appeal from the Defendant (9). The parties in this case did not file an appeal memory or counter memory appeal. In addition, there was no revocation of the appeal submitted by the appeal applicant. The Panel of Judges examining the case continued the examination of the case. Because there is no appeal or counter memory of the appeal submitted by the parties, the panel examined the appeal based on legal considerations in the decision issued by the Tangerang District Court Judges who examined the case. The decision by the Banten High Court Judge Panel examined the case contained in Decision Number 74 / Pdt / 2011 / PT.Btn dated October 27, 2011, namely: (1) received an appeal request from the Defendant originally named the Defendant; (2) upholding the Tangerang District Court Decision dated May 4, 2011 Number 475 / Pdt.G / 2010 / PN.TNG for which the appeal was filed; (3) Punishes the Comparator from the original Defendant for paying the costs of this case in the two court levels, which in the level of appeal is Rp. 150,000 (one hundred fifty thousand rupiah). The Banten High Court's decision that accepted the appeal by Tjoa Sin Goan as a comparison was in accordance with formal provisions. Examination of the appeal level continues to be carried out, even though the parties did not file an appeal or contra memory of the appeal to be considered by the panel of judges examining the case. This is in accordance with the principle that judges may not refuse to examine and try a case. The consideration of the panel of judges examining the case based on legal considerations at the first level is appropriate, because the panel is obliged to examine all parts of the suit and the panel may not decide beyond the suit. The action of the panel of judges at the appellate level is appropriate to examine the case by studying the legal considerations in the judge's decision at the first level (10).

Decision Number 74 / Pdt / 2011 / PT.Btn has been notified to the original Appellant Defendant on November 14, 2011, then on November 25, 2011 verbally stated the appeal request, as evidently in the deed of appeal application Number: 475 / Pdt.G / 2010 / PN. TNG and accompanied by Cassation Memory on December 9, 2011. The Respondent of Cassation / Plaintiff / Compared has submitted an answer to the cassation memory dated January 10, 2012. The Supreme Court in checking a case that after looking at the arguments put forward by the parties to convince the judges who hear cases and has done legal considerations. So that on 12 September 2012 makes decision indicated in the Decision No. 823 K / PDT / 2012 in the verdict as follows: (1) Reject the cassation of Cassation: Sin Tjoa Goan; (2) Punishing the Cassation Applicant / Plaintiff to pay the court fee in this cassation rate of Rp. 500,000 (five hundred thousand rupiah). The cassation decision on the case was then notified to the Plaintiff / Respondent of Cassation on May 2, 2013 and to the Defendant / Cassation Appellant on 8 May 2013. That as of the issuance and notification of the Supreme Court's Appeals in the case between the Dharmaputra Foundation against Tjoa Sin Goan, then the examination of the case of tort against the law has permanent legal force, so it is obligatory to carry out immediately. Based on the Cassation Decision Number: 823 K / PDT / 2012, the Defendant is obliged to implement the contents of Tangerang District Court's Decision Number 475 / PDT.G / 2010 / PN. TNG Jo. Banten District Court Decision Number: 74 / PDT / 2011 / PT.BTN. After the cassation decision is notified to the parties to the litigation, it must be implemented immediately. But it was not carried out voluntarily by Tjoa Sin Goan. Therefore sequestration that has been placed on the object land and buildings in Housing Modernland Jalan Putri Island VII VII 01 Block 42, Village
Coconut Beautiful, District of Tangerang, Tangerang City was supposed to have turned into a seizure of execution which means it can be run directly without the need for fixing the judge returned.

\subsection{Auction of building use rights that have expired}

Law and justice enforcement which becomes the authority of the judge as the organizer of part of the judicial power duties in the court, then in the context of implementing law enforcement purely and consistently by Sudikno Mertokusumo, it is said that there are 3 (three) elements that need to be taken into account, as follows: (1) legal certainty (rechtssicherheit); (2) expediency (zweckmassigkeit); (3) justice (gerechtigkeit). In realizing justice, benefits and legal certainty for the parties involved, the judge's decision is one manifestation of what is expected by the justice seeker community. Judges' decisions or often also called court decisions, are taken through a long mechanism, as a form and implement and enforce the law. Judges' decision in completing a case is expected not only to be seen in terms of statutory provisions, but also is expected to consider the sense of justice and its usefulness. Consideration of justice, expediency, and legal certainty must be realized for the sake of good law enforcement. The judge in deciding a case, casually, is always faced with the three principles, namely the principle of legal certainty, the principle of justice, and the principle of expediency. According to Sudikno Mertokusumo, the three principles must be carried out in a compromise, namely by applying all three in a balanced or proportional manner. Regarding this matter, the author agrees that the judge in deciding a case must not only emphasize one of the principles, but must be carried out in a balanced and proportional manner. As for the bidding process, the district court which decides the case and orders the sale of goods through an auction through the KPKNL, must submit a tender request letter accompanied by the tender requirements document to the Head of the KPKNL to request a schedule for the auction. The auction of goods in the form of land or land and buildings must be completed with SKT / SKPT (Land Certificate / Land Registration Certificate) from the local Land Office. Requests for issuing SKT / SKPT to the Head of the local Land Office are submitted by the Head of the KPKNL or Class II Auction Officer. Whereas in the case between the Tangerang Dharmaputra Foundation and the Toja Sin Goan in the form of SHGB and the validity period had expired. If the goods submitted for auction in the form of land and buildings to be auctioned are not yet registered at the local Land Office, the Head of the KPKNL or Class II Auction Officer requires the Seller to request a Certificate from the Village Chief / Village Head stating the ownership status of the Goods. Based on the aforementioned Certificate, the Head of the KPKNL or Class II Auction Officer requests a SKT / SKPT from the local Land Office. SKT / SKPT can be used more than 1 (one) time as a requirement document for auction application, as long as there is no change in physical data or juridical data of Goods in the form of land or land and buildings to be auctioned and ownership documents controlled by the Seller. In the event that there is no change in physical data or juridical data of the Goods in the form of land or land and buildings, the Seller must include this in the tender request letter. In the event of changes in physical data or juridical data of the Goods in the form of land or land and buildings to be auctioned again.

Auctions to be held can only be canceled based on a decision or decision from the judicial institution. The cancellation of the auction by the determination or decision of the judiciary is submitted in writing and must be received by 
the Bidding Officer no later than before the auction begins. In the event of a cancellation before the auction, the Seller and / or Bidding Officer must announce to the Bidder at the time of the auction. Auction Cancellation may also be submitted by the Auction Officer to cancel the auction if: (1) SKT / SKPT for the auction of goods in the form of land or land and buildings do not yet exist; (2) goods that will be auctioned in the status of confiscation of criminal or criminal block from the investigating agency or public prosecutor, specifically the Execution Auction; (3) there is a lawsuit over the planned implementation of Article 6 UUHT Execution Auction from parties other than the debtor / executed, debtor / executed husband or wife related to the ownership of the auction object; (4) goods to be auctioned in the status of confiscation or seizure of execution or confiscation of criminal, specifically Non-Execution Auction; (5) does not meet the Formal Legality of the Subject and Object of the Auction; (6) the seller cannot show or submit the original document of ownership of the Goods to the Bidding Officer; (7) Announcement of Auction conducted by the Seller is not in accordance with statutory regulations; (8) force majeure or force majeure; (9) there were technical problems that could not be overcome during the auction without the presence of participants; (10) The Limit Value stated in the Announcement of Auction is not in accordance with the letter of determination of the Limit Value made by the Seller; or (11) The seller does not physically control the movable goods auctioned. The auction must be preceded by the Announcement of the Auction made by the Seller in the auction for execution by the KPKNL. Announcement of Auction is carried out through a daily newspaper that is published and / or circulated in the city or district where the goods are located (8). In the event that there are no daily newspapers, the Announcement of Auction shall be announced in a daily newspaper published in the nearest city or district or in the provincial capital or state capital and circulates in the KPKNL working area or the area of the Class II Auction Officer's office where the goods will be auctioned. Announcement of Auction that has been published through daily newspapers, or through other media, if there are any known errors, it must be rectified immediately by the Seller. Auctions for Auction Announcement must be announced in the daily newspaper or the same media by designating the previous Auction Announcement and made at least 1 (one) working day before the auction day.

Auction Announcement must at least contain: (a) Seller's identity; (b) day, date, time and place of the auction being held; (c) type and quantity of goods; (d) location, land area, type of land rights, and the presence or absence of buildings, specifically for immovable property in the form of clan land or buildings; (e) goods specifications, especially for movable goods; (f) time and place of aanwijzing, in the event that the Seller carries out aanwijzing; (g) Bid auction guarantee includes the amount, time period, method and place of deposit, in the event that a bid auction is guaranteed; (h) Limit values, except Wood Auction and Other Forest Products from first hand and Voluntary Non-Execution Auctions for movable property; (i) how to bid; (j) the period of the Obligation to Pay for Auction by the Buyer; $(\mathrm{k})$ the KPKNL domain address or the Auction Hall conducting the auction by bidding through the internet, or the electronic mail address (KPKNL email or the Auction Hall or Class II Auction Officer who conducts the auction by auction bidding by electronic mail (email); Bid Auction. In conducting auctions, Auction Officers can be assisted by Auction Guides Auction Guides can come from DJKN employees or from outside DJKN employees. Bidding is done by: a. oral, increasing or decreasing; b. written; or c. written proceeding orally, in the event that the highest offer does not: $m$ reach a Limit Value. The auction must pay attention to the principles in the auction, namely: (1) Publicity or Transparency, meaning that each auction must be preceded by an auction announcement, either in the form of advertisements, brochures or invitations. Besides attracting as many bidders as possible perhaps the auction announcement is also intended to provide social control opportunities as a form of public protection. This principle is very important which forms the nature of the auction as a sale that is transparent. Therefore this principle is also called the transparency principle; (2) The Principle of Competition, namely because bidders are crossed and participants with the highest bid are in accordance with or above the limit price that will be declared the winner; (3) Certainty, which means that the Independence of the Bidding Officer should be able to make certainty that the highest bidder declared to be the winner of the auction, that the winner of the auction who has paid off his obligations will obtain goods and documents; (4) The principle of Accountability ( Accountability ), meaning that the implementation of the auction can be accounted for because the Government through the Auction Officer has the role to supervise the auction and make an authentic deed called the Auction Minutes which functions as a van transport deed. The auction official must be independent, meaning that he is not influenced or impartial to anyone, so that this principle can also be said to be the principle of independence; (5) Principle of Efficiency, meaning that because an auction is conducted at a specified time and place and transactions occur at that time, it can obtain cost and time efficiency because thus goods can be quickly converted into money.

The auction as an agreement shows the legal character of the sale and purchase, namely (1) there are two parties to the agreement, namely the seller and the buyer, (2) there is an agreement or agreement between the seller to transfer the ownership rights to the goods to the buyer and the buyer's agreement to submit the amount of money at the sales price , (3) there are goods which are the object of buying and selling, (4) there is a certain price agreed in the form of money, (5) a consensual / obligatory agreement, giving rise to the rights and obligations of the seller and buyer, (6) the transfer of ownership occurs after the agreement material / submission based on auction minutes. The minutes of the auction are made to record the agreement between the seller and buyer of the auction at the obligation agreement stage. For this reason, auction officials are responsible for the authenticity of the auction minutes. The minutes of the auction have the power of proof. Minutes of auction that meet the elements of an authentic deed as regulated in Article 1868 of the Civil Code and Article 1870 of the Civil Code. The minutes of auction have three authentic deed elements, which are required, namely (1) the form of auction minutes has been determined by Article 37, 38, 39 Vendu Reglement, (2) auction minutes made before the Bidding Officer as a Public Official in accordance with Article 1a Vendu Reglement, (3) the minutes of the auction must be made by an authorized Auction Officer in the region in accordance with Article 7 Vendor Reglement. Auction minutes that have the power of formal proof, auction officials are responsible for making auction minutes that guarantee the truth / certainty of the auction date, the signatures of the parties to the minutes, the identities of the people present at the auction, namely the seller, auction participant and auction buyer, thus also where auction sales are held. The minutes of the auction, which have the power to prove material, in terms of information contained in the minutes of the auction, are valid, so that when used as 
evidence before a court, it is considered sufficient and the judge is allowed to ask for other proofs. Submission of juridical (juridische levering) immovable objects in the auction object, with registration / transfer of name at the Land Office. Linked to the UUPA, the process of transfer of ownership that has been recorded through the auction is as follows: (1) The first phase, which precedes the minutes of the auction treaty, in the form of a consensual / obligatory agreement, which is the causa of the transfer of rights, when the auction official as the attorney for the law the law of the seller agrees with the highest bidder buyer, in the appointment of the auction buyer by the auction official. (2) The second phase, the minutes of the auction treaty, the auction official as the attorney for the law of the seller and buyer sets out the will regarding the submission in the minutes of the auction treaty. Thus the treatise on auctions such as deed and power of land rights as evidence to be able to register. (3) The third phase, when the auction buyer registers at the land office. The third phase of registering at the land office as levering / surrender occurs when the transfer of name at the Land Office is based on auction minutes. The transfer of rights based on the sale and purchase of auctions is the return of the name of the certificate holder to the purchaser of the auction based on the auction minutes published by the Auction Office.

The most essential thing in auctions and buying and selling is the delivery of goods which become objects in the sale and purchase or auction and payment of the price of the object. The elements contained in the sale and purchase are also contained in the auction, namely the existence of legal subjects, sellers and buyers, an agreement between the seller and the buyer regarding the price, the rights and obligations arising for the parties, between the seller and the buyer. Basically the auction is the sale of goods to the public or in public. The validity of the transfer of rights with this auction is proven by the existence of the minutes of auction made before the authorized auction officials, in this civil case between the Dharmaputra Foundation as the Plaintiff against Tjoa Sin Goan as Defendant, class 1 auction official appointed by the Tangerang City KPKNL. The sale of auctions originating from the execution of collateral items, the auction is carried out by order of the law by the competent authority, not from the owner of the goods.

\section{Conclusion}

In the case of this civil case between the Dharmaputra Foundation as the Plaintiff against Tjoa Sin Goan as the Defendant, which was the object of confiscation in the form of a plot of land and the house was located on Jalan Pulau VII VII Block 01 No. 42 Modernland, Kota Tangerang, based on Building Certificate No. 651 / Kelapa Indah. Certificate of Building Use Certificate Number 651 / Kelapa Indah based on a Certificate from the National Land Agency of the Republic of Indonesia Tangerang City Land Office Banten Province, on October 17, 2016, the National Land Agency of the Republic of Indonesia Land Office of Tangerang City of Banten Province in its letter number 3449 / 600.13-36.71 / X / 2018 concerning the Request for Information on SHGB 651 / Kelapa Indah, addressed to Felix Dalimartha, SH, as attorney from Mr. Heru Soetanto Putra Law Office of Dalimartha \& Partners Ruko Metropolis Mall Blok GM 2 Number 7, in Tangerang, issued by the Head of Office Tangerang City Land H.Badrus Salim, SH dated Tangerang, 17 October 2016, in essence explains that (1) Certificate of Building Use Rights Number 651 / Kelapa Indah, Measurement Letter dated May 22, 2008 Number 155 / Kelapa Indah / 2008 covering 234 m2 (two hundred and thirty-four square meters) registered in the name of Lenawati Mardjuki and their rights expired on 9
February 2013 ; (2) Certificate of Right to Building number 651 / Kelapa Indah originating from the Certificate of Right to Building number 610 / Cikokol based on Tangerang City Regulation number 16/2000 dated November 28, 2000, Cikokol Village is expanded into Kelapa Indah Village ; (3) Building Rights Certificate number 651 / Kelapa Indah there is a Blocking note based on a letter from the Dalimartha \& Partners Law Office dated 24 November 2010 because there is a lawsuit Number 475 / Pdt.G / 2010 / PN.TNG. The plot of land and house is located on Pulau Putri VII Block 01 No. 42 Modernland, Kota Tangerang, based on the Building Use Certificate Number 651 / Kelapa Indah, which has expired on February 9, 2013, basically the basis for the land rights of the object is returned to the State. The status of the land rights is no longer the Right of Building for ownership of Lenawati Mardjuki but has become the status of state-owned land since 9 February 2013

\section{Ethical issue}

Authors are aware of, and comply with, best practice in publication ethics specifically with regard to authorship (avoidance of guest authorship), dual submission, manipulation of figures, competing interests and compliance with policies on research ethics. Authors adhere to publication requirements that submitted work is original and has not been published elsewhere in any language.

\section{Competing interests}

The authors declare that there is no conflict of interest that would prejudice the impartiality of this scientific work.

\section{Authors' contribution}

All authors of this study have a complete contribution for data collection, data analyses and manuscript writing.

\section{References}

1. Paranage K. The consequences of restricting rights to land: understanding the impact of state-land tenure policies in Sri Lanka. Sustainability: Science, Practice and Policy. 2018;14:4654. DOI: $10.1080 / 15487733.2018 .1545556$

2. Wildan S, Sita. Eksekusi Kejurusitaan Pengadilan Cet-1. Jakarta: Tatanusa. 2004:39-40.

3. M Yahya Harahap. Hukum Acara Perdata Gugatan, Persidangan, Penyitaan, Pembuktian, dan Putusan Pengadilan. Jakarta: Sinar Grafika. 2017. 397.

4. Supramono, Gatot. Perjanjian Utang Piutang. Jakarta: Kencana Prenada Media Group. 2013:180-181.

5. Dr. H. Zainal Asikin. Hukum Acara Perdata Di Indonesia Jakarta: Prenadamedia Grup. 2015;158.

6. Cremers K, Schliessler P. Patent litigation settlement in Germany: why parties settle during trial. Eur J Law Econ. 2015;40:185-208. https://doi.org/10.1007/s10657-014-9472-x

7. Hadiprayitno I. Hazard or Right? the dialectics of development practice and the internationally declared right to development, with special reference to Indonesia. Intersentia, Indonesia. 2009. ISBN 978-90-5095-932-2

8. Zaputra A. effectiveness of executive auction responsibility as a problem credit settlement in pt.bank mandiri(persero) tbk purwokerto Area. Authentica. 2018;1:112-125. DOI: 10.20884/1.atc.2018.1.2.12

9. Wijayanti R, Harahap B. Creditor rights on rejection of execution request for guarantee rights by state and auction private. International Journal of Multicultural and Multireligious Understanding. 2019;6:25. DOI:10.18415/ijmmu.v6i1.480.

10. Wiryomartono B. Traditions and Transformations of Habitation in Indonesia. Springer Publication, Singapore. DOI https://doi.org/10.1007/978-981-15-3405-8. 